\title{
The E. Coli Pyrogen Test in human liver disease
}

\author{
By G. O. Schlütz'1), J. Venulet and E. E. Bittar \\ From the "Institute of Researcb" of the University of Damascus, Damascus, Syria, Division Enzymology"
}

(Director: Professor Dr. med. G. O. Schliit?.)

(Der Schriftleitung zugegangen am 10. Oktober 1964)

Much study has been devoted to the subject of the pathogenesis of fever (1). VENULET and co-workers (2-5) have investigated the peripherial mechanism of action of lipopolysaccharide isolated from $E$. Coli and have shown that the pyrogen response in rabbits is accompanied not only by hyperglycemia but by a decrease in blood lactic acid. These workers, moreover, have localized the cellular site of action of pyrogen in that the activity of mitochondrial succinic dehydrogenase in liver cells is increased at the peak of the temperature rise. The succinic dehydrogenase activity was measured by the method of Slater and BonNer involving the blockage of cytochrome activity by cyanide and the acceptance of $\mathrm{H}_{2}$ by methylene blue (6).

In another series of experiments the response of rabbits to pyrogen was studied in association with the action of Lysergic acid diethylamide (LSD) which is a central stimulator as well as 2,4-Dinitrophenol (DNP) which is a peripheral stimulator (7). The results indicate that the $\mathrm{O}_{2}$ consumption of liverslices increases following the use of DNP but the hyperthermic response itself is temporarily abolished in the presence of $\mathrm{CCl}_{4}$-induced liver damage. In the case of LSD, its effect is maintained in spite of liver damage and the $\mathrm{O}_{2}$ consumption remains unchanged. The implication here ist that pyrogen exerts a peripheral effect. - The above data suggests that the pyrogen test might be used to distinguish between the various forms of liver disease (8). For example, it would be predicted that patients with diffuse liver damage such as that occuring in infectious hepatitis would react less intensely to pyrogen than normal humans.

With this in mind, we studied the pyrogen response in three groups of humans: Ten human subjects free of liver disease, eleven patients with infectious hepatitis and eleven patients with cirrhosis.

Pyrogen was given intravenously in a dose of one microgramm. The lipopolysaccharide was isolated by the method of PALMer and Gerlough (9), as modified by WestPHAL, LuDERITZ, EICHENBERgER and KeIDERLING (10). Half hourly temperatures were recorded until the temperature began to level off. Blood for liver function tests was drawn before and after the use of pyrogen (bromsulphaleine, SGPT, SGOT, alkaline phosphatase, thymol turbidity, cephalin floculation and bilirubin tests). The table shows the mean temperature rise in the three groups of people studied together with the SGOTand SGPT-values.

The mean temperature rise for the normals is $1,45^{\circ}$, for the cirrbotics $1,85^{\circ}$ and for the bepatitics $1,03^{\circ}$. - It was noted by us, too, that most of the hepatitics, unlike the other patients, failed to complain of chills, headache und muscle aches.

In summary, the pattien with hepatitis responds to $E$. Coli pyrogen less intensely than normal humans, while the cirrhotic responds in exagerated fashion. Why this is so with the cirrhotic is perhaps a matter of succinic dehydrogenase activity and we plan to measure the activity of this enzyme in liver biopsy specimens before and after pyrogen administration.

Our thanks are due to Boehringer und Soehne Company, Mannheim-Waldhof, Germany, for kindly providing us with their test kits for enzyme-activity determination.

1) Paper red in part at the autumn meeting of the German Biocbemical Society, Cologne, October, 22/24, 1964.

Tab: Average temperature rise in three groups of human subjects secondary to $1 \mu \mathrm{g}$ of lipopolysaccharide given intravenously

\begin{tabular}{|c|c|c|c|c|c|c|c|c|c|c|c|c|}
\hline \multicolumn{4}{|c|}{ Control } & & \multicolumn{4}{|c|}{ Other liver diseases } & \multicolumn{4}{|c|}{ Infectious Hepatitis } \\
\hline Nr. & $\Delta \mathrm{t}^{0}$ & SGOT & SGPT & & Nr. & $\Delta \mathrm{t}^{0}$ & SGOT & SGPT & Nr. & $\Delta t^{0}$ & - SGOT & SGP'T \\
\hline 1 & 1,5 & 17. & 0 & & 11 & 2,1 & 37 & 18 & 22 & 1,8 & 175 & 316 \\
\hline 2 & 1,4 & $25^{\circ}$ & 15 & & 12 & 1,2 & 187 & 296 & 23 & 1,0 & & 1820 \\
\hline 3 & 1,3 & 25 & 18 & & 13 & 1,5 & 112 & 107 & 24 & 1,3 & 152 & 350 \\
\hline 4 & 0,9 & 30 & 8 & & 14 & 1,8 & 32 & 16 & 25 & 0,7 & 25 & 176 \\
\hline 5 & 2,2 & 90 & 3 & & 15 & 1,5 & 67 & 36 & 26 & 2,2 & 175 & 870 \\
\hline 6 & 1,1 & 32 & 21 & - & 16 & 1,9 & 67 & 32 & 27 & 0,4 & 150 & 242 \\
\hline 7 & 1,6 & 4 & 10 & & 17 & 1,7 & 75 & 57 & 28 & 0,7 & 75 & 100 \\
\hline 8 & 1,8 & 30 & 29 & & 18 & 2,1 & 61 & 42 & 29 & 0,5 & 155 & 230 \\
\hline 9 & 1,5 & 37 & 25 & & 19 & 2,5 & 92 & 30 & 30 & 1,2 & 135 & 135 \\
\hline 10 & 1,2 & 42 & 25 & & 20 & 1,7 & 75 & 45 & 31 & 1,0 & 75 & 111 \\
\hline & & & & & 21 & 2,4 & 112 & 100 & 32 & 0,5 & 12 & 117 \\
\hline Average & 1,45 & 26 & 15 & & & 1,85 & 82 & 70 & & 1,03 & 102 & 3997 \\
\hline
\end{tabular}




\title{
References
}

1. Atrkins, E., Physiol. Rev. 40, 580 (1960). - 2. DesperakNacinzek, A. and J. Venulet, Acta physiol. polon. 11, 623 (1960). - 3. Venulet, J. and A. Desperak-Naciazek, J. Pharmacy Pharmacol. 12, 656 (1960). - 4. Venulet, J. and A. DesperakNaciazek, Experientia (Basel) 13, 365 (1957). - 5. Venulet, J. and A. Desperak-Naciazek, Arch. int. Pharmacodynam. Thérap. 144, 465 (1963). - 6. Slater, E. C. and W. D. Bonner, Biochem.
J. 52, 185 (1952). - 7. Desperak-Naciazek, A. and J. Venulet, Unpublished results. - 8. Schlütz, G. O., J. VenUlet and E. E. Bitrak, Sixth Int. Congress of Biochemistry, New York, August 1964. (Abstracts V/145.) - 9. Palmer, I. W. and D. T. Gerlough, Science (New York) 92, 155 (1940). - 10. Westphal, O., O. Luderitz, E. Eichienberger and W. KeIDERLiNG, $Z$. Naturforschg. 7b, 536 (1952).
Professor Dr. med. G. O. Schlütz

Center of Research,

University of Damascus

Damascus, Syria

\section{Permanent address}

Med.-Chem. Laboratorium Dr. Schlütz 78 Freiburg i. Br.

\section{Fermente des menschlichen Blutes ${ }^{1}$ )}

\section{Mitteilung: Mikromethode zur Bestimmung der Enzymaktivität des Serums und der Erythrozyten für sieben verschiedene Substrate}

\author{
Von W. Pilz \\ Aus dem plyysiologisch-cbemischen und analytischen Labor (Dr. W. Pilz) der Ärztlichen Abteilung (Dr. H. Hörlein) \\ der Farbenfabriken Bayer AG., Werk Leverkusen
}

(Der Schriftleitung zugegangen am 22. September 1964)

\begin{abstract}
Es wird eine zusammengefaßte Darstellung der Bestimmung der Serumesterasen (Substrate: Acetylcholin, Benzoylcholin, $\alpha$-Naphthylpropionat, $\beta$-Naphthylpropionat, Phenylacetat, Monosuccinylcholin, Disuccinylcholin) und der Erythrozytencholinesterase gegeben. Für alle Substrate ist die Beziehung zwischen eingesetzter Serummenge und gespaltener Estermenge an jeweils 4 verschiedenen Sera untersucht worden. Substratkonzentration und Menge des eingesetzten biologischen Materials sind so geregelt, daß man sich stets im linearen Teil dieser Beziehung bewegt. Für alle Serumesterasebestimmungen sind nur 3,0 ml Serum notwendig. $\mathrm{Da}$ in allen Fällen die Substratkonzentration konstant ist und die Resultate einheitlich in $U / \mathrm{m} / / \mathrm{Std}$. angegeben werden, können die Werte untereinander verglichen werden. Als Beleganalysen wurden das Mittel aus 250 Normalpersonen sowie die Esteraseaktivitäten eines Falles von verlängerter Apnoe nach Succinylcholin und eines Falles von Myotonie angegeben.
\end{abstract}

The determination of serum esterases (substrates: acetylcholine, benzoylcholine, $\alpha$-naphthylpropionate, $\beta$ - naphthylpropionate, phenylacetate, monosuccinylcholine, disuccinylcholine) and erythrocyte cholinesterases is reviewed. The relationship between the amount of serum used and the amount of ester hydrolysed with 4 different sera was investigated for every substrate. The substrate concentration and the amount of added biological material are standardized in order to obtain the linear part of this relationship. Only $3.0 \mathrm{~m} l$ of serum are necessary for each serum esterase determination. Since the substrate concentration is constant in all cases and the results are given uniformly as units $/ \mathrm{m} l / \mathrm{hr}$, the values can be compared. As test analyses, the average esterase activities of 250 normal persons, a case of prolonged apnoea after succinylcholine, and a case of myotonia are given.

In letzter Zeit häufen sich die Fälle, in denen nach Applikation von Disuccinylcholin eine stark verlängerte Apnoe auftritt. Die Verlängerung der Apnoe, wobei es zu lebensbedrohlichen Zuständen kommt, wird nach der neuesten Version von BArTsCH (2) auf ein mangelndes Spaltvermögen des menschlichen Serums für die Droge als Folge der Verminderung von atypischen Pseudocholinesterasen zurückgeführt. Daß diese Version problematisch ist, konnten wir vor kurzem beweisen (1). $\mathrm{Da}$ jedoch in der Mehrzahl der Fälle von verlängerter Apnoe, die bisher untersucht wurden, atypische Pseudocholinesterasen gefunden wurden, sollte man von der Möglichkeit der enzymatischen Analyse bei allen Patienten, bei denen eine Anästhesie mit Succinylcholin vor-

1) X. Mitteilung: siehe Literatur (1). gesehen ist, Gebrauch machen und bei allen jenen, die abnorme Fermentwerte haben, von der Applikation des Relaxans Abstand nehmen, um Narkosezwischenfälle zu vermeiden. - Es muß betont werden, daß ein ursächlicher Zusammenhang zwischen verlängerter Apnoe nach Succinylcholin und dem gleichzeitigen Vorhandensein atypischer Esterasen bisher nicht bewiesen werden konnte, sondern $\mathrm{da} \beta$ es sich dabei lediglich um eine Erfahrungstatsache handelt. Es ist zum Beispiel nicht bekannt, wieviele Fälle von verlängerter Apnoe auftraten, die normale Esterasen hatten; andererseits liegen Untersuchungen über die Häufigkeit von Trägern atypischer Esterasen vor, von denen nicht bekannt ist, wie sie auf Succinylcholin reagieren $(3,4)$.

$\mathrm{Am}$ häufigsten wurde zur Feststellung atypischer Esterasen die sogenannte Dibucainnummer (5) oder die 